\title{
ANALISIS MANFAAT EKONOMI DAN IDENTIFIKASI RISIKO INVESTASI SISTEM TREASURY DEALING ROOM (TDR): STUDI KASUS DIREKTORAT JENDERAL PERBENDAHARAAN
}

\author{
Bagus Utomo \\ Direktorat Jenderal Perbendaharaan \\ Alamat Korespondensi: bagus.pippo@gmail.com
}

\section{INFORMASI ARTIKEL}

Diterima Pertama

23 Juli 2018

Dinyatakan Diterima

06 Desember 2018

KATA KUNCI:

Treasury Dealing Room (TDR), tabel manfaat SI/TI generik, kerangka pikir kesejahteraan digital, system dynamics, COSO ERM Framework.

\section{KLASIFIKASI JEL:}

Economic Development, Innovation, Technological Change, and Growth.

\begin{abstract}
ABSTRAK
Minister of Finance has the authority to manage state finances covering cash and securities. To increase Non-Tax State Revenue and reduce the cost of funding, the Directorate General of Treasury build Treasury Dealing Room (TDR). The Budget for information system/information technology (IS/IT) is 74\% of the total project budget. This study aims to analyze the economic benefits of TDR system investment. Generic IS/IT business value table is used to identify the benefits for the organization and digital prosperity framework for the country. Systems dynamics is used to analyze the interrelationship between business benefits to obtain key business benefits. Quantification is based on IT metrics and assumptions on calculating the value of TDR funds. This research also identifies risks using COSO Enterprise Risk Management-Integrated Framework. Thematic analysis is used to process qualitative data. The results show that investment of TDR systems can reduce the cost of money (RCO-09), increasing revenue caused by increasing business capacity (IRE-01) and widening market segment (IRE-04). The total value of benefits from 2016-2020 (five years) amounted to Rp655.294.873.957. The benefits for the country are increasing efficiency and a larger and more efficient market. Eleven potential risks covering regulatory, coordination, technology, and human resources aspects are obtained.
\end{abstract}

Menteri Keuangan bertugas mengelola keuangan negara yang mencakup kas dan surat berharga. Untuk meningkatkan Penerimaan Negara Bukan Pajak serta mengurangi biaya menghimpun dana, Direktorat Jenderal Perbendaharaan berinisiatif membangun Treasury Dealing Room (TDR). Anggaran investasi sistem informasi/teknologi informasi (SI/TI) mencapai $74 \%$ dari total biaya proyek. Penelitian ini bertujuan menganalisis manfaat ekonomi investasi sistem TDR. Metode yang digunakan untuk identifikasi manfaat bisnis bagi organisasi adalah tabel manfaat bisnis SI/TI generik, sedangkan kerangka pikir kesejahteraan digital digunakan untuk identifikasi manfaat bagi negara. Pendekatan system dynamics digunakan untuk menganalisis keterkaitan antar manfaat bisnis sehingga diperoleh manfaat bisnis utama. Kuantifikasi dilakukan berdasarkan metrik TI dan asumsi-asumsi perhitungan nilai dana TDR. Penelitian ini juga melakukan identifikasi risiko menggunakan COSO Enterprise Risk Management-Integrated Framework. Analisis tematik digunakan untuk mengolah data yang bersumber dari wawancara, diskusi, dan studi dokumen. Hasil penelitian menunjukkan bahwa investasi sistem TDR mampu mengurangi biaya uang/bunga pinjaman (RCO09), meningkatkan pendapatan yang disebabkan oleh meningkatnya kapasitas bisnis (IRE-01) dan segmentasi pasar (IRE-04). Total nilai manfaat ekonomi dari tahun 2016-2020 (lima tahun) sebesar Rp655.294.873.957. Manfaat investasi sistem TDR bagi negara yaitu meningkatkan efisiensi dan pasar yang lebih luas dan efisien. Berdasarkan identifikasi risiko, diperoleh sebelas potensi risiko yang mencakup aspek peraturan, koordinasi, teknologi, dan SDM. 


\section{PENDAHULUAN}

\subsection{Latar Belakang}

Sesuai dengan Peraturan Pemerintah Nomor 39 tahun 2007 tentang Pengelolaan Uang Negara/Daerah, Menteri Keuangan selaku Bendahara Umum Negara (BUN) bertugas mengelola keuangan negara yang mencakup pengelolaan kas dan surat berharga, termasuk kegiatan untuk menanggulangi kekurangan kas atau memanfaatkan kelebihan kas secara optimal. Pengalaman krisis tahun 1997 dan tuntutan publik atas tata kelola pemerintahan yang baik meningkatkan kesadaran akan perlunya reformasi pengelolaan keuangan publik (public finance management) yang komprehensif, dengan salah satu penekanan utamanya adalah pengelolaan kas (Kementerian Keuangan RI dan Bank Dunia, 2014).

Landasan awal reformasi pengelolaan kas yang ada di Indonesia adalah pelaksanaan Rekening Tunggal Perbendaharaan (Treasury Single Account, TSA) (Kementerian Keuangan RI dan Bank Dunia, 2014). Dengan adanya TSA maka semua penerimaan dan pengeluaran Anggaran Pendapatan dan Belanja Negara (APBN) dikelola melalui Rekening Kas Umum Negara (RKUN) di Bank Indonesia (BI). Sebagai konsekuensi penerapan TSA, saldo kas pemerintah di BI menjadi besar dan memiliki pola berulang dengan rata-rata saldo harian sekitar Rp94 triliun pada tahun 2012 dan Rp60 triliun pada tahun 2013 (Kementerian Keuangan RI dan Bank Dunia, 2014). Pada bulan Januari 2009, Kementerian Keuangan dan BI bersepakat dan menerapkan remunerasi atas saldo kas pemerintah di BI sebesar 65\% dari suku bunga BI (Kementerian Keuangan RI dan Bank Indonesia, 2009).

Penerapan remunerasi telah meningkatkan PNBP, namun demikian, tingkat remunerasi masih lebih rendah dibandingkan dengan tingkat suku bunga yang berlaku di pasar domestik, sebagai contoh tingkat suku bunga Jakarta Interbank offered Rate (JIBOR). Remunerasi juga lebih rendah dibandingkan dengan biaya pinjaman melalui penerbitan Surat Berharga Negara (SBN). Menurut Kementerian Keuangan dan Bank Dunia (2014), rata-rata tingkat imbal hasil SBN dalam setahun adalah 7,5\% (tahun 2011), 6,5\% (tahun 2012), dan $8,62 \%$ (tahun 2013). Dengan demikian terjadi biaya menghimpun dana (carrying cost) negatif karena remunerasi yang diperoleh lebih rendah dari biaya pinjaman yang dikeluarkan oleh pemerintah.

Dalam rangka meningkatkan PNBP pengelolaan kas serta mengurangi biaya menghimpun dana, pemerintah dalam hal ini Kementerian Keuangan melihat potensi untuk lebih memaksimalkan saldo kas menganggur (idle cash), yaitu dengan memperluas instrumen investasi. Investasi yang semula sebatas penempatan uang negara di BI akan diperluas menjadi penempatan uang negara di bank umum, pengelolaan SBN dan valuta asing (valas). Untuk dapat melakukan perluasan instrumen investasi tersebut, diperlukan suatu sarana transaksi online yang terhubung dengan pasar keuangan baik dalam maupun luar negeri. Oleh karena itu, Kementerian Keuangan c.q. Direktorat Jenderal Perbendaharaan memutuskan untuk membangun sebuah dealing room. Dari keseluruhan biaya proyek pembentukan TDR, 74\% digunakan untuk investasi sistem informasi/teknologi informasi (SI/TI).

\subsection{Rumusan Masalah}

Peppard dan Ward (2016) menyatakan perlunya pengelolaan manfaat (benefits management) untuk mencapai manfaat dari proyek SI/TI. Benefits management didefinisikan sebagai suatu proses pengorganisasian dan pengelolaan sedemikian rupa sehingga potensi manfaat/keuntungan yang timbul dari penggunaan TI benar-benar terealisasi. Model proses ini tidak hanya menekankan penilaian sebelum investasi (pre-investment appraisal) dan evaluasi setelah investasi (post-investment evaluation), namun juga bagaimana organisasi dapat secara aktif mengelola manfaat yang diklaim di awal agar terealisasi. Model proses pengelolaan manfaat ditunjukkan oleh Gambar 1.

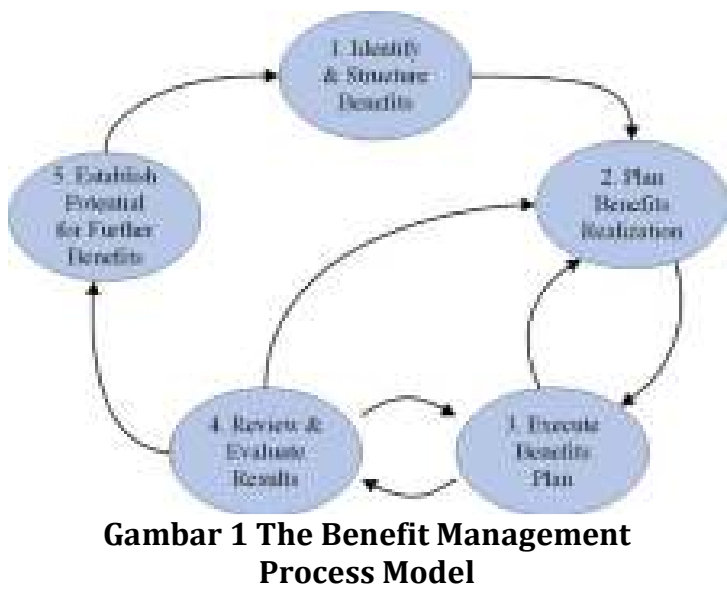

(Sumber: Peppard dan Ward, 2016)

Berdasarkan teori-teori di atas, suatu organisasi perlu mengkaji lebih lanjut apakah investasi yang telah dilakukan mampu memberikan manfaat sesuai dengan tujuan investasi. Fokus penelitian ini adalah identifikasi dan kuantifikasi manfaat yang merupakan bagian dari tahapan pertama benefits management process model, yaitu identify and structure benefits. Selain itu, penelitian ini juga akan melakukan identifikasi risiko yang merupakan bagian dari tahapan kedua benefits management process model, yaitu plan benefits realization. 


\section{KERANGKA TEORI DAN PENGEMBANGAN HIPOTESIS}

\subsection{Dealing Room}

Berdasarkan Peraturan Menteri Keuangan RI Nomor 115/PMK.05/2016, dealing room adalah sebuah ruangan yang digunakan untuk melakukan transaksi pengelolaan kelebihan atau kekurangan kas, dengan dilengkapi alat komunikasi, perekam, dan perangkat pendukung lainnya. Tujuan utama pembangunan TDR adalah pengelolaan likuiditas, yaitu memastikan pemerintah dapat memenuhi kewajibannya secara efektif dan efisien. Tujuan utama tersebut selanjutnya diturunkan menjadi empat pilar prioritas, yaitu likuiditas terjaga, minimalisasi risiko dan biaya, transparan dan akuntabel, serta optimalisasi return (PNBP) (Direktorat Pengelolaan Kas Negara, 2016).

\subsection{Tabel Manfaat Bisnis SI/TI Generik}

Ranti (2008) menjelaskan bahwa bagian tersulit dan terpanjang dalam justifikasi investasi SI/TI adalah menguantifikasi atau mengonversi manfaat SI/TI yang diklasifikasikan sebagai manfaat intangible (soft value) ke dalam nilai uang agar analisis manfaat-biaya (cost-benefit analysis) lebih akurat. Ranti (2008) melakukan penelitian untuk mengidentifikasi dan mengklasifikasikan manfaat bisnis SI/TI menggunakan pendekatan hermeneutic. Sumber data penelitian berasal dari 60 kasus implementasi proyek SI/TI pada berbagai jenis perusahaan yang ada di Indonesia. Hasil penelitian tersebut berupa kerangka manfaat bisnis umum dari suatu proyek SI/TI, yang selanjutnya disebut Tabel Manfaat Bisnis SI/TI Generik. Penggunaan tabel manfaat bisnis SI/TI generik dapat mempermudah kajian investasi TI, terutama dalam hal identifikasi manfaat TI. Tabel ini menghilangkan perbedaan manfaat tangible dan intangible, sehingga organisasi dapat langsung menentukan manfaat yang didapatkan dari investasi TI (Ranti dan Nugroho, 2017).

\subsection{Kesejahteraan Digital}

Kesejahteraan digital (digital prosperity) merupakan sebuah penelitian yang mengkaji manfaat revolusi teknologi informasi terhadap kesejahteraan suatu negara (Atkinson dan McKay, 2007). Tidak diragukan lagi bahwa revolusi TI telah meningkatkan kualitas hidup, mulai dari peningkatan fasilitas kesehatan, kemudahan mencari informasi dan proses belajar, memberikan kenyamanan interaksi konsumen dengan bisnis dan pemerintah serta kemudahan mengukur kualitas lingkungan. Meskipun semua manfaat tersebut penting, dapat dikatakan bahwa manfaat terpenting dari revolusi TI adalah dampaknya terhadap pertumbuhan ekonomi. Atkinson dan McKay (2007) menyatakan bahwa dampak revolusi TI terhadap pertumbuhan ekonomi terdapat pada lima area kunci, yaitu: (1) Produktivitas, (2) Pekerjaan, (3) Pasar yang lebih efisien, (4) Barang dan jasa berkualitas tinggi, dan (5) Inovasi produk dan jasa. Peningkatan dari kelima area kunci tersebut pada akhirnya berpengaruh pada kesejahteraan yang tercermin dari pendapatan per kapita dan GDP yang lebih tinggi.

Berdasarkan kerangka pikir kesejahteraan digital (Atkinson dan McKay, 2007), kelima area kunci tersebut didukung oleh tujuh kategori manfaat, yaitu (1) rantai pasokan yang fleksibel, (2) kesempatan kerja yang mudah diakses dan fleksibel, (3) meningkatkan efisiensi, (4) kualitas barang dan layanan yang lebih tinggi, (5) alat pengambilan keputusan yang lebih baik, (6) pasar yang lebih luas dan efisien, dan (7) alat penelitian baru.

\subsection{System Dynamics}

System dinamics adalah metodologi untuk mempelajari dan mengelola sistem umpan balik yang kompleks, seperti yang ditemukan dalam bisnis dan sistem sosial lainnya (Kanungo, 2003). Metodologi ini dikembangkan oleh Jay Forrester pada tahun 1950-an (Sterman, 2000). Pemodelan pada system dinamics dapat digambarkan menggunakan dua diagram sebagai berikut:

1. Diagram Causal Loop

Binder et al. (2004) menyatakan Causal Loop Diagrams (CLDs) digunakan untuk mendokumentasikan faktor -faktor yang relevan dan hubungan sebab akibat antar faktor-faktor tersebut. CLDs terdiri dari faktor dan garis penghubung (link) yang menghubungkan faktor. Setiap link memiliki polaritas (polarity).

2. Diagram Stock and Flow

Diagram lain yang dapat digunakan dalam system dynamic adalah Stock and Flow Diagrams (SFDs). Binder et al. (2004) menyatakan SFDs mampu memperbaiki ambiguitas dan kurangnya detail yang ada pada CLDs dengan menyediakan simulasi sistem model. Beberapa peneliti mengemukakan untuk menggunakan CLDs saat brainstorming, kemudian beralih ke SFDs untuk memodelkan sistem secara tepat. Dengan demikian, CLDs dapat digunakan sebagai dasar untuk SFDs.

\subsection{Metrik TI}

Ranti dan Nugroho (2017) mendefinisikan metrik TI sebagai sekumpulan ukuran yang digunakan untuk kuantifikasi manfaat TI. Infotech (2008) menjelaskan bahwa metrik TI mengukur aktivitas komponen dari proses, orang, atau produk melalui sistem pengukuran yang telah ditentukan. Metrik TI merupakan penghitungan 
atau formula sederhana yang mengukur dan mengelola proses TI seperti pengembangan perangkat lunak, pemeliharaan aplikasi, operasi produksi, keamanan, rasio pegawai, dan sebagainya. Infotech (2008) menjelaskan kriteria metrik yang baik adalah SMART (specific, measurable, attainable, repeatable, dan timedependent). Setiap metrik dibuat dengan tujuan masing-masing, tergantung dari karakteristik organisasi. Pada penelitian ini metrik TI berbasis nilai/manfaat akan digunakan untuk melakukan kuantifikasi manfaat dari investasi sistem TDR.

\subsection{COSO Enterprise Risk Management- Integrated Framework}

COSO Enterprise Risk Management-Integrated Framework (COSO ERM Framework) mendefinisikan Manajemen Risiko Organisasi (Enterprise Risk Management) sebagai proses yang dipengaruhi oleh Dewan Direksi (Board of Directors), manajemen, dan personil lain dalam entitas, diaplikasikan pada pembentukan strategi dan pada seluruh bagian perusahaan, dirancang untuk mengidentifikasi kejadian potensial yang dapat mempengaruhi entitas, dan mengelola risiko selaras dengan selera risiko (risk appetite) entitas, untuk menyediakan jaminan yang wajar terhadap pencapaian sasaran dari entitas (Beasley, Branson, dan Hancock, 2010).

Beasley, Branson, dan Hancock (2010) menyatakan bahwa organisasi perlu mengetahui indikator terdepan mengenai munculnya risiko baik di lingkup internal maupun eksternal. Key Risk Indicator (KRI) merupakan metrik yang digunakan oleh organisasi untuk memberikan tanda awal (early signal) peningkatan eksposur risiko dari berbagai area perusahaan. Tujuan pengembangan KRI yang efektif adalah mengidentifikasi metrik yang relevan yang memberikan pandangan tentang potensi risiko yang mungkin berdampak pada pencapaian tujuan organisasi. Dalam rangka penanganan risiko, KRI dapat digunakan untuk menginisiasi tindakan mengurangi risiko yang berkembang (mitigasi risiko) dengan melakukan pemantauan terhadap KRI tersebut oleh unit organisasi yang telah ditunjuk (Beasley et al., 2010).

\subsection{Kerangka Teoretis}

Berdasarkan teori yang telah dijelaskan serta penelitian-penelitian yang telah dilakukan sebelumnya, dibangun sebuah kerangka teoretis yang diperlihatkan pada Gambar 2. Mengacu Gambar 2, identifikasi manfaat bisnis bagi organisasi dilakukan menggunakan tabel manfaat bisnis SI/TI generik (Ranti, 2008). System dynamics (Binder et al., 2004) digunakan untuk mengelompokkan manfaat bisnis yang relevan dan signifikan berdasarkan keterkaitan atau hubungan sebab akibat. Untuk mengetahui manfaat investasi sistem TDR bagi negara, digunakan kerangka pikir kesejahteraan digital (Atkinson dan McKay, 2007). Kuantifikasi manfaat bisnis utama dilakukan berdasarkan metrik TI dan asumsi-asumsi perhitungan nilai dana TDR untuk mendapatkan nilai finansial dari manfaat bisnis utama investasi sistem TDR. COSO ERM Framework (Beasley, Branson, dan Hancock, 2010) digunakan sebagai acuan dalam mengidentifikasi potensi risiko serta KRI yang mungkin muncul dan dapat menghambat pencapaian manfaat investasi sistem TDR. Penelitian sebelumnya digunakan sebagai panduan bagaimana melaksanakan identifikasi, pemodelan, simulasi, kuantifikasi manfaat serta identifikasi risiko. Penelitian sebelumnya terdiri dari empat penelitian yang dilakukan oleh Prasetya (2017), Amri (2014), Larasati (2014), dan Nugroho (2015).

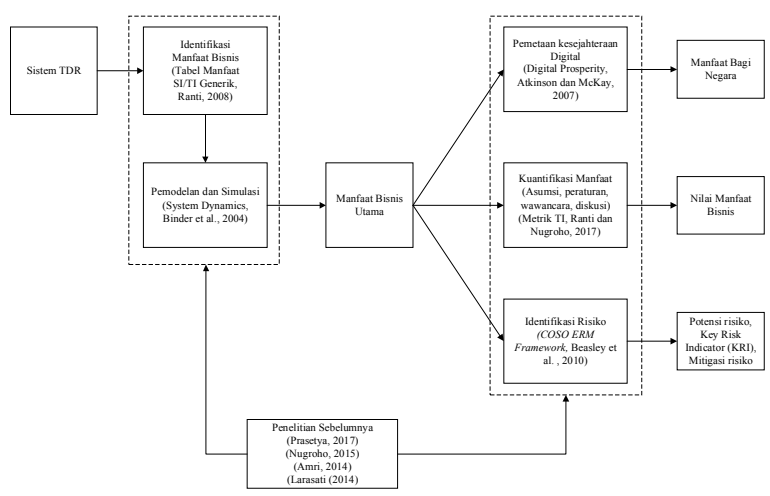

Gambar 2 Kerangka Teoretis

\section{METODOLOGI PENELITIAN}

Penelitian ini merupakan jenis penelitian kualitatif dengan logika induktif di mana penelitian dimulai dari pengumpulan data untuk mengeksplorasi fenomena, mengidentifikasi tema dan pola kemudian membangun sebuah conceptual framework (Saunders, Lewis, dan Thornhill, 2016). Selain itu penelitian ini juga termasuk dalam penelitian terapan (applied research) dengan paradigma penelitian pragmatis (pragmatism). Saunders, Lewis, dan Thornhill (2016) menjelaskan penelitian terapan bertujuan meningkatkan pemahaman permasalahan pada suatu organisasi kemudian menghasilkan solusi atas permasalahan tersebut. Pada penelitian ini, alur penelitian terdiri dari sembilan tahapan seperti terlihat pada Gambar 3.

\subsection{Metode Pengumpulan Data}

Pada penelitian ini, data yang dikumpulkan berasal dari dua sumber, yaitu data primer dan data sekunder. Data primer adalah data yang diperoleh langsung dari sumber asli dengan menggunakan instrumen dan metode tertentu. Berbeda dengan data primer, data sekunder merupakan data yang sudah tersedia sebelumnya. Metode pengumpulan data yang digunakan dalam penelitian ini adalah sebagai berikut: 


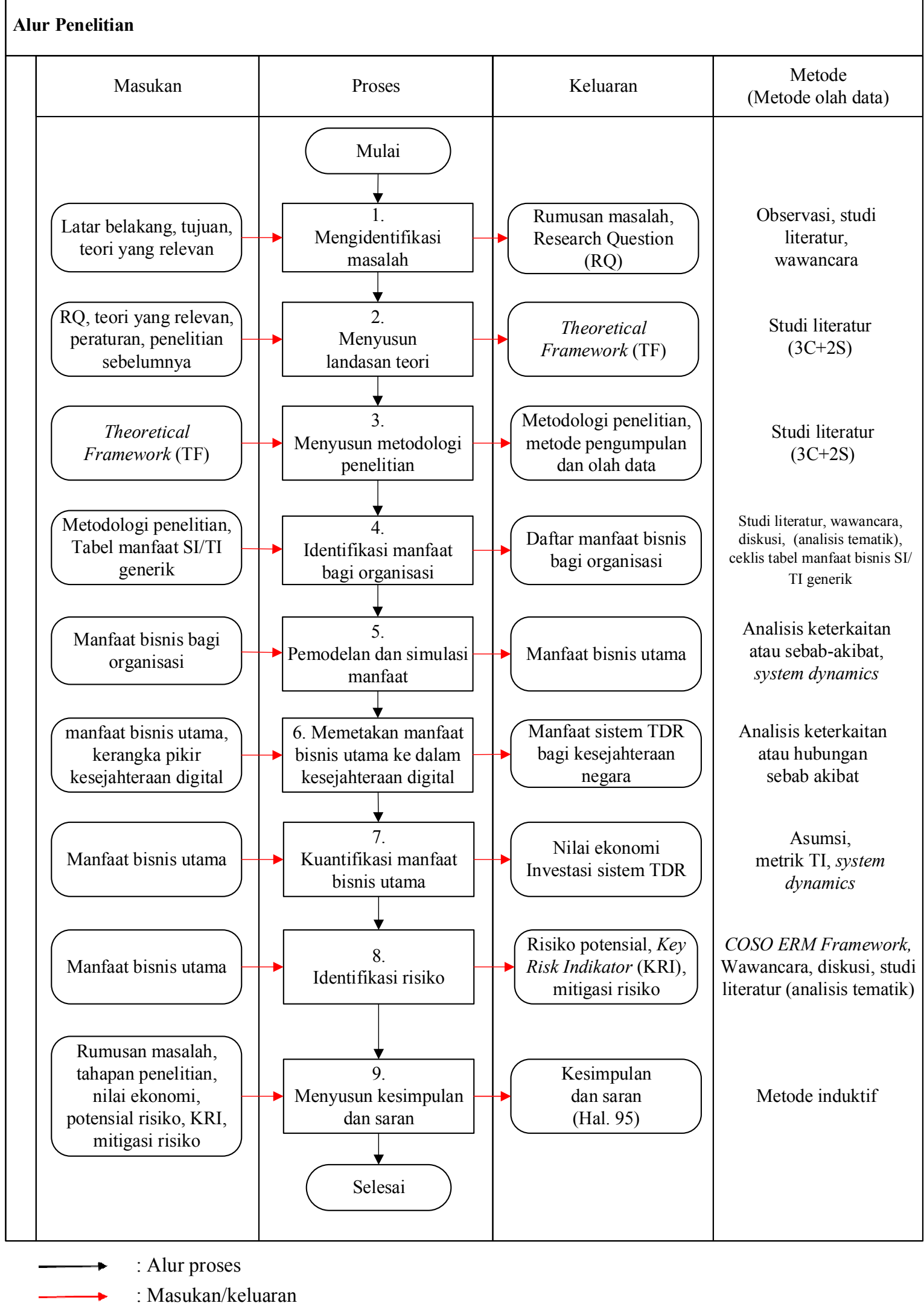


1. Wawancara

Metode wawancara yang digunakan adalah wawancara tidak terstruktur (unstructured interviews). Sekaran dan Bogie (2013) menjelaskan bahwa wawancara tidak terstruktur bertujuan membawa beberapa masalah awal ke permukaan sehingga peneliti dapat menentukan faktor yang perlu dikaji lebih dalam. Jenis pertanyaan wawancara yang digunakan dalam penelitian ini adalah pertanyaan terbuka (open-ended questions). Pertanyaan terbuka dirancang untuk mendapatkan informasi sebanyak mungkin dan memberikan narasumber keleluasaan untuk menyampaikan informasi. Narasumber berasal dari pihak internal Ditjen Perbendaharaan dan eksternal (bank umum).

2. Checklist tabel manfaat bisnis SI/TI generik Pada penelitian ini, checklist tabel manfaat bisnis SI/TI generik ditujukan kepada pegawai TDR meliputi bagian front office, middle office, dan back office untuk mengonfirmasi/validasi hasil identifikasi manfaat bisnis investasi sistem TDR.

3. Observasi

Observasi merupakan tindakan terencana untuk mengamati, merekam, menganalisis, dan menginterpretasi perilaku, tindakan, atau peristiwa (Sekaran dan Bogie, 2013). Pada penelitian ini, observasi dilakukan untuk melengkapi data yang diperoleh dari wawancara terkait investasi sistem TDR pada Ditjen Perbendaharaan.

4. Studi dokumen

Menurut Creswell (2012), dokumen yang dikumpulkan dalam penelitian dapat berupa dokumen umum atau dokumen pribadi. Pada penelitian ini, studi dokumen dilakukan untuk mendapatkan bukti atau dokumentasi dari investasi sistem TDR.

\subsection{Metode dan Proses Olah Data}

Pada penelitian ini, data yang digunakan merupakan data periode tahun 2016 dan 2017, sedangkan data tahun 2018 sampai dengan 2020 menggunakan asumsi berdasarkan hasil wawancara dan data historis. Jenis data yang digunakan adalah data kualitatif yang berasal dari wawancara, diskusi, dan studi dokumen yang bertujuan memperoleh informasi terkait investasi sistem TDR. Metode olah data kualitatif yang digunakan dalam penelitian ini adalah analisis tematik. Clarke dan Braun (2013) mendefinisikan analisis tematik sebagai metode untuk mengidentifikasi, menganalisis, dan melaporkan pola-pola (tema) dalam data. Pengolahan data kualitatif menggunakan urutan langkah analisis tematik menurut Clarke dan Braun (2013), sebagai berikut:
1. Pengenalan data

Langkah ini dilakukan dengan membaca data (transkrip hasil wawancara dan hasil studi dokumen) berulang kali sehingga mampu mengenal data secara mendalam, serta menuliskan observasi analitis awal dari hasil pengenalan data tersebut.

2. Pengkodean (coding)

Coding dilakukan dengan memberikan label bagian penting dari data yang sesuai dengan pertanyaan penelitian. Setelah pengkodean selesai, langkah selanjutnya menyusun seluruh kode serta ekstrak data yang relevan.

3. Pencarian tema

Tema merupakan pola yang koheren dan bermakna pada data yang relevan dengan pertanyaan penelitian. Pencarian tema dilakukan dengan memberikan kode pada pengkodean dengan tujuan mengidentifikasi kemiripan data.

4. Mengulas tema

Pemeriksaan tema serta data secara keseluruhan. Dalam langkah ini dimungkinkan untuk menggabungkan dua tema bersamaan atau memecah sebuah tema ke dalam dua atau lebih tema, atau membatalkan seluruh kandidat tema yang ada dan memulai kembali langkah penentuan tema.

5. Pendefinisian dan penamaan tema

Langkah ini dilakukan dengan penulisan untuk masing-masing tema, identifikasi esensi dari masing-masing tema, serta pembentukan nama tema yang ringkas, tepat dan informatif.

6. Penulisan tema

Penulisan dilakukan dengan penyusunan narasi analitis serta ekstrak data sehingga menjadi sebuah cerita yang koheren dan persuasif, dan penyesuaian dengan konteks literatur yang ada.

\section{HASIL PENELITIAN}

Investasi sistem TDR dilatarbelakangi oleh adanya potensi untuk memaksimalkan idle cash pemerintah. Tujuan investasi sistem TDR adalah 4 (empat) pilar prioritas, yaitu likuiditas terjaga, minimalisasi risiko dan biaya, transparan dan akuntabel, dan optimalisasi return (Direktorat Pengelolaan Kas Negara, 2016). Mengingat Kementerian Keuangan c.q. Ditjen Perbendaharaan merupakan organisasi publik, maka manfaat dari investasi sistem TDR tidak hanya dirasakan oleh organisasi, namun juga oleh negara secara keseluruhan. Hubungan manfaat investasi sistem TDR ditunjukkan oleh Gambar 4. Berdasarkan Gambar 4, manfaat bisnis utama yang dihasilkan melalui identifikasi menggunakan tabel manfaat bisnis SI/TI generik (Ranti, 2008) dan pendekatan 
system dynamics (Binder et al., 2004) akan dibandingkan dengan tujuan investasi yang telah ditetapkan oleh organisasi.

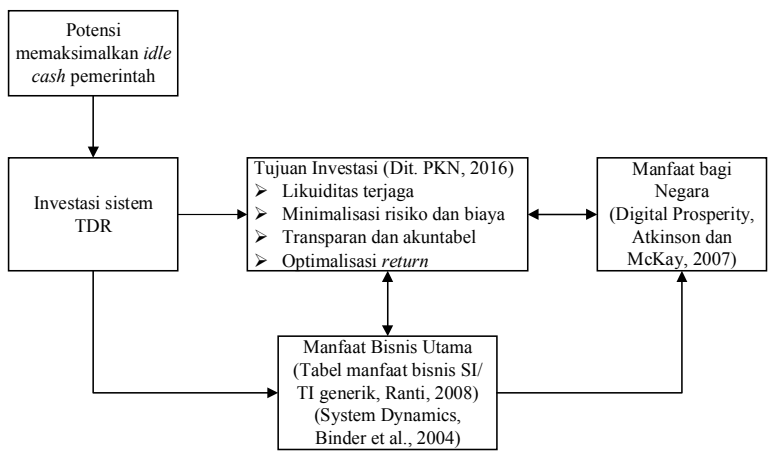

Gambar 4 Manfaat Investasi Sistem TDR

Selanjutnya untuk mengetahui manfaat investasi sistem TDR bagi negara, manfaat bisnis utama tersebut akan dipetakan menggunakan kerangka pikir kesejahteraan digital (Atkinson dan McKay, 2007). Bersama dengan tujuan manfaat investasi sistem TDR, manfaat bisnis utama bagi organisasi dan manfaat bagi negara akan dipetakan untuk mengetahui hubungan atau keterkaitan antar manfaat tersebut.

\subsection{Identifikasi Manfaat Bisnis Sistem TDR bagi Organisasi}

Berdasarkan hasil wawancara, penulis melakukan identifikasi manfaat bisnis sistem TDR menggunakan tabel manfaat bisnis SI/TI generik.

Hasil identifikasi selanjutnya dikonfirmasi kepada pengguna sistem TDR menggunakan checklist tabel manfaat bisnis SI/TI generik. Checklist ditujukan kepada 13 responden yang merupakan pegawai TDR dilevel pelaksana/staf meliputi bagian front office, middle office, dan back office. Pemilihan 13 responden berdasarkan pertimbangan bahwa responden memiliki kompetensi selaku pengguna sistem TDR dan ikut terlibat dalam pembentukan TDR, sehingga memahami tujuan dan manfaat sistem TDR. Manfaat bisnis yang teridentifikasi merupakan manfaat yang saat ini sudah dirasakan/ditemukan di organisasi serta potensi manfaat yang mungkin dapat dicapai berdasarkan pemanfaatan sistem dealing room di bank umum dengan pertimbangan proses bisnis dan karakteristik organisasi. Berdasarkan hasil identifikasi tersebut, terdapat 7 kategori manfaat dan 18 subkategori manfaat bisnis yang relevan dan signifikan bagi organisasi sebagaimana terlihat pada Tabel 1.

Tabel 1 Manfaat Bisnis yang Relevan dan Signifikan

\begin{tabular}{|c|c|c|}
\hline Kategori & Subkategori & Kode \\
\hline Mengurangi/menekan biaya (dari) & 1. Biaya uang (bunga pinjaman) & RCO-09 \\
\hline \multirow{2}{*}{$\begin{array}{l}\text { Meningkatkan produktivitas } \\
\text { (karena disebabkan oleh) }\end{array}$} & 2. Restrukturisasi pembagian fungsi kerja & IPR-01 \\
\hline & 3. Kemudahan analisis & IPR-03 \\
\hline \multirow[t]{4}{*}{ III. Mempercepat proses (dari) } & 4. Proses pembuatan laporan & APR-03 \\
\hline & 5. Proses persiapan data & APR-04 \\
\hline & 6. Proses transaksi & APR-07 \\
\hline & 7. Proses pengambilan keputusan & APR-08 \\
\hline \multirow[t]{5}{*}{ IV. Mengurangi risiko (dari) } & 8. Kesalahan hitung & RRI-01 \\
\hline & 9. Kehilangan data & RRI-05 \\
\hline & 10. Kesalahan data & RRI-06 \\
\hline & 11. Jatuh tempo & RRI-07 \\
\hline & 12. Kesalahan pembayaran & RRI-11 \\
\hline \multirow{2}{*}{$\begin{array}{l}\text { Meningkatkan pendapatan (yang } \\
\text { disebabkan oleh) }\end{array}$} & 13. Meningkatkan kapasitas bisnis & IRE-01 \\
\hline & 14. Meningkatkan segmentasi pasar & IRE-04 \\
\hline \multirow[t]{3}{*}{ VI. Meningkatkan keakuratan (dari) } & 15. Analisis & IAC-02 \\
\hline & 16. Data & IAC-03 \\
\hline & 17. Keputusan & IAC-05 \\
\hline VII. Meningkatkan kualitas (dari) & 18. Hasil kerja & IQU-02 \\
\hline
\end{tabular}

\subsection{Pemodelan Manfaat Bisnis Sistem TDR Menggunakan System Dynamics}

Dalam rangka menghasilkan manfaat utama sistem TDR serta menghindari duplikasi manfaat pada saat kuantifikasi, dilakukan analisis keterkaitan atau hubungan sebab akibat antar manfaat bisnis yang relevan dan signifikan. Metode system dynamics digunakan untuk menggambarkan keterkaitan dalam bentuk diagram yang selanjutnya dilakukan simulasi menggunakan aplikasi bantu yang mendukung metode system dynamics. Diagram causal loop berfungsi menggambarkan keterkaitan/interaksi seluruh manfaat bisnis dalam hubungan sebab akibat untuk mencapai tujuan investasi teknologi informasi, dalam hal ini sistem TDR. Diagram causal loop manfaat investasi sistem TDR seperti terlihat pada Gambar 5 . Diagram stock and flow berfungsi menggambarkan simulasi model yang merepresentasikan perubahan yang ditimbulkan oleh manfaat bisnis sistem TDR dalam hubungan 
sebab akibat yang sebelumnya telah digambarkan menggunakan causal loop diagram. Diagram stock and flow sistem TDR dapat dilihat pada Gambar 6 .

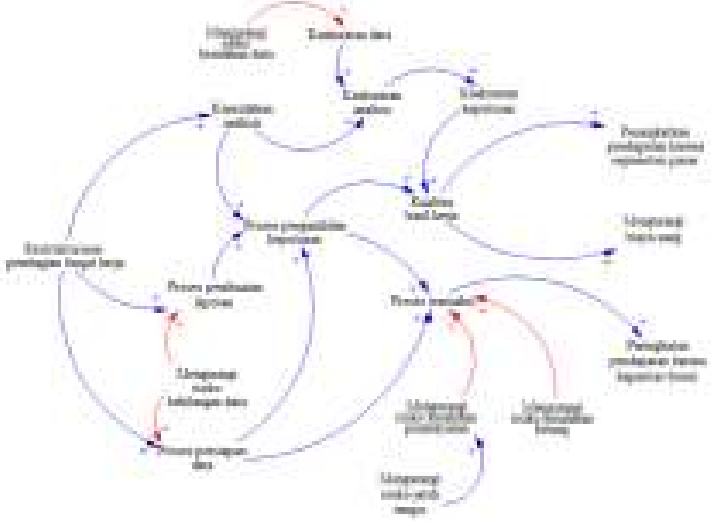

Gambar 5 Causal Loop Diagram Manfaat Sistem TDR

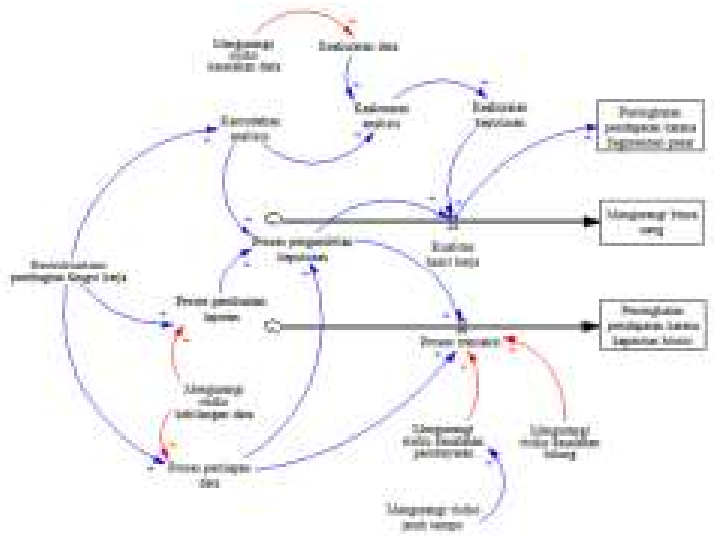

Gambar 6 Stock and Flow Diagram Manfaat Sistem TDR

Manfaat bisnis utama berperan sebagai stock, yang menggambarkan manfaat dari investasi sistem TDR, sedangkan variabel manfaat lainnya berperan sebagai flow yang akan mempengaruhi pencapaian manfaat investasi tersebut. Hasil pemodelan diagram stock and flow adalah manfaat bisnis utama seperti terlihat pada Tabel 2.

Tabel 2 Manfaat Bisnis Utama Sistem TDR

\begin{tabular}{|l|l|l|c|}
\hline No & \multicolumn{1}{|c|}{ Kategori } & Subkategori & Kode \\
\hline 1. & $\begin{array}{l}\text { Mengurangi/ } \\
\text { menekan biaya } \\
\text { (dari) }\end{array}$ & $\begin{array}{l}\text { Biaya uang } \\
\text { (pinjaman) }\end{array}$ & RC0-09 \\
\hline 2. & $\begin{array}{l}\text { Meningkatkan } \\
\text { pendapatan } \\
\text { (disebabkan } \\
\text { oleh) }\end{array}$ & $\begin{array}{l}\text { Meningkatkan } \\
\text { kapasitas } \\
\text { bisnis }\end{array}$ & IRE-01 \\
\hline 3. & $\begin{array}{l}\text { Meningkatkan } \\
\text { pendapatan } \\
\text { disebabkan } \\
\text { oleh) }\end{array}$ & $\begin{array}{l}\text { Meningkatkan } \\
\text { segmentasi } \\
\text { pasar }\end{array}$ & IRE-04 \\
\hline
\end{tabular}

Metrik TI untuk ketiga manfaat tersebut adalah perubahan pengeluaran karena pengurangan biaya uang (RCO-09) dan perubahan pendapatan karena peningkatan kapasitas bisnis (IRE-01) dan peningkatan segmentasi pasar (IRE-04). Dalam rangka pengolahan data menggunakan analisis tematik, ketiga manfaat manfaat utama tersebut digunakan sebagai dasar pengkodean data. Kode yang digunakan adalah ICAP yang menggambarkan peningkatan kapasitas bisnis (increase capacity), ISEG yang menunjukkan peningkatan segmentasi (increase segmentation), dan RCOS yang menunjukkan pengurangan biaya (reduce cost).

Sebagaimana telah dijelaskan sebelumnya, analisis manfaat ekonomi sistem TDR mengidentifikasi manfaat yang saat ini sudah terealisasi serta potensi manfaat yang bisa dicapai oleh organisasi dengan mengacu pada pemanfaatan sistem dealing room di perusahaan lain (best practices), dalam hal ini di bank umum. Ketiga manfaat bisnis utama sistem TDR yang dihasilkan dari pemodelan system dynamics meliputi 3 (tiga) instrumen investasi, yaitu pengelolaan valas, penempatan uang di bank umum, dan pengelolaan investasi SBN. Dari ketiga instrumen tersebut, saat ini baru satu instrumen yang sudah terealisasi, yaitu penempatan uang di bank umum, sedangkan dua instrumen lainnya masih bersifat potensi atau sedang dalam proses realisasi. Status manfaat utama sistem TDR dapat dijelaskan sebagai berikut:

1. Mengurangi/menekan biaya uang/bunga pinjaman (RCO-09)

Manfaat ini berstatus potensi karena BI belum mengizinkan pemerintah bertransaksi valas dengan pihak lain. Nominal transaksi yang besar dikhawatirkan dapat mempengaruhi nilai kurs serta adanya kemungkinan berlawanan dengan kebijakan moneter yang dilakukan oleh BI. Apabila nominal yang ditransaksikan relatif kecil, kemungkinan transaksi dengan pihak lain, dalam hal ini bank umum dapat dilakukan.

2. Meningkatkan pendapatan yang disebabkan oleh meningkatnya kapasitas bisnis (IRE-01) Manfaat ini merupakan manfaat yang telah terealisasi karena sistem TDR telah digunakan dan mampu meningkatkan kapasitas bisnis dalam transaksi penempatan uang negara di bank umum.

3. Meningkatkan pendapatan yang disebabkan oleh meningkatnya segmentasi pasar (IRE-04)

Manfaat ini terdiri dari dua instrumen investasi, yaitu penempatan uang negara di bank umum, di mana sistem TDR telah digunakan dan mampu meningkatkan pendapatan (realisasi). Instrumen yang kedua yaitu pengelolaan investasi SBN yang masih bersifat potensi. BI telah mengizinkan pemerintah dalam hal ini Ditjen 
Perbendaharaan untuk melakukan pengelolaan investasi SBN. Peraturan dan platform yang dibutuhkan saat ini sedang dalam tahap finalisasi. Pengelolaan investasi SBN melalui sistem TDR diharapkan sudah dapat dilakukan pada tahun 2018.

Sebenarnya terdapat satu lagi instrumen investasi yang dapat dimasukkan dalam peningkatan segmentasi pasar, yaitu pengelolaan valas. Pengelolaan valas dalam rangka trading lazim dilakukan oleh bank umum. Namun demikian, pengelolaan valas oleh pemerintah sampai saat ini masih dalam rangka pemenuhan likuiditas, tidak untuk trading. Sejauh ini BI belum mengizinkan pemerintah bertransaksi valas dengan pihak di luar BI dengan pertimbangan dapat mempengaruhi nilai kurs serta risiko kerugian dari aktivitas trading forex cukup besar. Faktor nominal transaksi menjadi pertimbangan karena dapat mengganggu tugas utama BI dalam rangka menjalankan kebijakan moneter. Berdasarkan pertimbangan di atas, maka pengelolaan valas tidak dimasukkan dalam kuantifikasi peningkatan pendapatan yang disebabkan oleh meningkatnya segmentasi pasar.

\subsection{Identifikasi Manfaat Bisnis Sistem TDR bagi Negara}

Biaya pembangunan dan dana yang dikelola oleh TDR Ditjen Perbendaharaan bersumber dari dana APBN. Sumber utama penerimaan APBN adalah sektor perpajakan, yang merupakan kontribusi warga terhadap keberlangsungan Negara Kesatuan Republik Indonesia (NKRI). Oleh karena itu, selain identifikasi manfaat bisnis bagi organisasi, penelitian ini juga melakukan identifikasi manfaat sistem TDR bagi negara. Identifikasi manfaat bagi negara dilakukan menggunakan kerangka pikir kesejahteraan digital (Atkinson dan McKay, 2007). Proses identifikasi dilakukan dengan cara memetakan manfaat bisnis utama hasil pemodelan system dynamics sesuai Tabel 2 ke dalam 7 kategori manfaat berdasarkan kerangka pikir kesejahteraan digital.

Manfaat sistem TDR yang dirasakan oleh organisasi, dalam hal ini Direktorat Jenderal Perbendaharaan, pada akhirnya akan memberikan dampak kepada negara secara menyeluruh. Gambar 7 menunjukkan 3 (tiga) manfaat bisnis utama yang dihasilkan oleh sistem TDR berdasarkan tabel manfaat bisnis SI/TI generik memberikan dampak pada 2 (dua) kategori manfaat bagi negara berdasarkan kerangka pikir kesejahteraan digital, yaitu meningkatkan efisiensi dan menyediakan pasar yang lebih luas dan efisien. Keterkaitan manfaat bisnis utama sistem TDR terhadap kesejahteraan digital dapat dijelaskan sebagai berikut:
1. Meningkatkan efisiensi

Pemanfaatan sistem TDR dalam pengelolaan kas negara meningkatkan efisiensi baik sumber daya manusia (SDM), waktu, maupun modal. Peningkatan efisiensi SDM ditandai dengan pengurangan operator yang dibutuhkan untuk melakukan transaksi. Berdasarkan hasil wawancara dengan Kepala Seksi Pengelolaan Rekening Lainnya Milik Kementerian/Lembaga selaku tim penilai penempatan dana reboisasi, proses penentuan pemenang/pemilihan bank umum dilakukan oleh tim penilai yang beranggotakan sekitar 10 orang, ditambah dengan bagian penyelesaian transaksi (settlement) sekitar 3 orang.

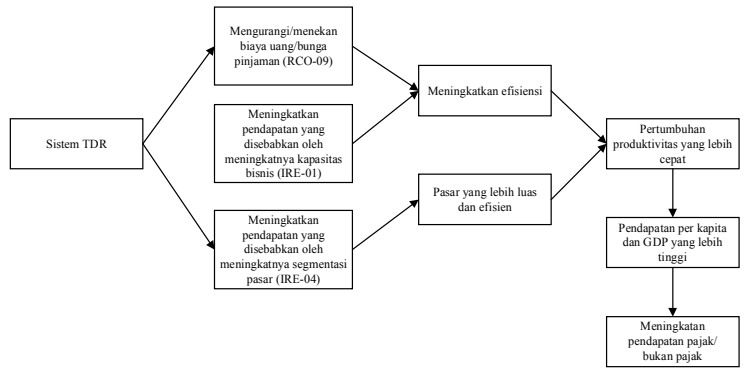

Gambar 7 Manfaat Sistem TDR bagi Negara

Dengan sistem TDR, penentuan pemenang/pemilihan bank umum sampai dengan penyelesaian transaksi diselesaikan oleh 4 orang.

Dari segi waktu, proses penempatan dana reboisasi yang dilakukan secara manual membutuhkan waktu 3 hari mulai dari proses penjelasan (aanwijzing), penyampaian dokumen penawaran, penilaian, dan penyelesaian transaksi. Dengan sistem TDR, waktu yang dibutuhkan untuk menyelesaikan satu kali transaksi adalah 1-2 jam. Selain pada proses transaksi, peningkatan efisiensi dari segi waktu juga bisa terlihat dari proses pembuatan laporan dan persiapan data yang dapat meningkatkan produktivitas serta pendapatan bagi organisasi.

Peningkatan efisiensi juga dirasakan dari segi biaya (modal). Dengan menggunakan sistem TDR, terdapat alternatif dalam memenuhi kekurangan kas. Sebelumnya kebutuhan kas hanya dapat dipenuhi melalui penerbitan SBN, namun dengan sistem TDR, kebutuhan kas juga dapat dipenuhi melalui pinjaman (borrowing) ke bank umum atau dengan melakukan reverse repo SBN. Peningkatan efisiensi terbesar adalah mengurangi biaya uang/bunga pinjaman, dalam hal ini konversi valas. Sebelum penggunaan sistem TDR, konversi valas hanya dapat dilakukan dengan BI. Dengan sistem TDR, konversi valas dapat dilakukan dengan bank umum dan diperoleh rate yang lebih kompetitif.

Dengan adanya peningkatan efisiensi dari segi SDM, waktu, dan biaya (modal), pemerintah dapat mengurangi biaya yang harus dikeluarkan. Di sisi 
lain, peningkatan efisiensi juga mampu mendorong peningkatan PNBP dari pengelolaan kas negara. Jumlah penghematan sumber daya dan peningkatan PNBP tersebut dapat dialokasikan untuk program/pembangunan lainnya yang produktif, sebagai contoh pembangunan infrastruktur telekomunikasi. Mengutip situs Masyarakat Telematika Indonesia (www.mastel.id), sektor telekomunikasi antara perkotaan dan daerah di Indonesia harus seimbang, namun saat ini masih terjadi ketimpangan yang disebabkan oleh ketersediaan infrastruktur yang kurang memadai. Infrastruktur telekomunikasi merupakan fondasi penting untuk menjalankan dan mengembangkan sektor komunikasi dan informatika di dalam negeri. Dengan infrastruktur yang lebih baik, maka produktivitas juga akan meningkat, sehingga pada akhirnya dapat meningkatkan pendapatan per kapita dan Produk Domestik Bruto (PDB).

Metrik TI peningkatan efisiensi yang disebabkan oleh investasi sistem TDR adalah sebagai berikut:

\section{Metrik TI : Meningkatkan efisiensi}

Formula

= pengurangan biaya uang (bunga pinjaman) + peningkatan pendapatan yang disebabkan oleh meningkatnya kapasitas bisnis.

Penjelasan

Dana yang diperoleh dari penghematan dan peningkatan pendapatan PNBP diasumsikan digunakan untuk pembangunan infrastruktur telekomunikasi yang merupakan fondasi untuk menjalankan dan mengembangkan sektor komunikasi dan informatika sehingga meningkatkan pendapatan per kapita dan PDB.

\section{Pasar yang lebih luas dan efisien}

Penggunaan sistem TDR menghubungkan pemerintah dengan pasar keuangan. Pemerintah sebelumnya hanya dapat menempatkan kelebihan kas negara di BI dan menutup kekurangan kas melalui penerbitan SBN yang dilakukan oleh DJPPR. Dengan sistem TDR, pemerintah dapat bertransaksi langsung di pasar keuangan dengan bank umum. Hal ini menyebabkan pemerintah memiliki alternatif dalam memperoleh maupun memanfaatkan kelebihan dana. Pada saat kelebihan dana, pemerintah dapat melakukan penempatan di bank umum atau membeli/melakukan reverse repo SBN. Sementara pada saat kekurangan dana, pemerintah dapat melakukan peminjaman (borrowing) kepada bank umum atau menjual/melakukan repo SBN. Penambahan instrumen tersebut dapat meminimalkan biaya perolehan dana serta meningkatkan pendapatan dari pengelolaan kas negara.
Terciptanya pasar yang lebih luas dan efisien dapat dilihat dari dua sudut pandang yang berbeda. Pertama, sama seperti halnya peningkatan efisiensi, pengurangan biaya perolehan dana dan peningkatan pendapatan dari pengelolaan kas dapat dialokasikan untuk program/pembangunan lainnya, sebagai contoh pembangunan infrastruktur telekomunikasi. Kedua, masuknya pemerintah ke pasar keuangan dapat meningkatkan kedalaman pasar keuangan. Mengacu pada pengembangan dan pendalaman pasar keuangan (Kementerian Keuangan RI, Bank Indonesia, dan Otoritas Jasa Keuangan, 2016), pembiayaan pembangunan sangat diperlukan guna mencapai pertumbuhan ekonomi yang tinggi, berkesinambungan, dan inklusif. Pasar keuangan yang dalam, aktif, likuid, inklusif, dan efisien adalah prasyarat untuk meningkatkan ketersediaan dana bagi pembangunan. Dengan pasar keuangan yang semakin dalam, pembiayaan untuk pembangunan infrastruktur dapat terpenuhi sehingga dapat mendorong pertumbuhan ekonomi dan meningkatkan PDB. Metrik TI pasar yang lebih luas dan efisien yang disebabkan oleh investasi sistem TDR adalah sebagai berikut:

\section{Metrik TI : Pasar yang lebih luas dan efisien \\ Formula dan Penjelasan \\ = Pengurangan biaya perolehan dana + peningkatan pendapatan yang disebabkan oleh meningkatnya segmentasi pasar.}

Dana yang diperoleh dari pengurangan biaya perolehan dana dan dan peningkatan pendapatan PNBP diasumsikan digunakan untuk pembangunan infrastruktur telekomunikasi yang merupakan pondasi untuk menjalankan dan mengembangkan sektor komunikasi dan informatika sehingga meningkatkan pendapatan per kapita dan PDB.

= Nominal penempatan uang di bank umum + nominal pembelian/reverse repo SBN

Jumlah uang negara yang masuk ke pasar keuangan melalui TDR membantu meningkatkan kedalaman pasar. Dengan pasar keuangan yang semakin dalam, pembiayaan untuk pembangunan infrastruktur dapat terpenuhi sehingga dapat mendorong pertumbuhan ekonomi dan meningkatkan PDB.

Manfaat investasi sistem TDR bagi kesejahteraan digital tidak dilakukan kuantifikasi karena keterbatasan data. Namun demikian, berdasarkan analisis yang telah dikemukakan di atas, dapat disimpulkan bahwa investasi sistem TDR memberikan dampak positif bagi kesejahteraan negara. 
Dalam rangka mengetahui manfaat investasi sistem TDR secara keseluruhan, dilakukan analisis keterkaitan manfaat bisnis utama, tujuan investasi, dan manfaat kesejahteraan digital seperti terlihat pada Tabel 3. Tabel 3 menunjukkan bahwa bahwa investasi sistem TDR tidak hanya berhasil mencapai tujuan investasi yang ditetapkan oleh organisasi, namun juga mampu memberikan manfaat bisnis utama bagi organisasi serta manfaat bagi kesejahteraan nasional. Proses yang transparan dan akuntabel muncul pada semua manfaat bisnis utama sistem TDR. Proses ini meningkatkan kualitas kerja dan mempercepat proses transaksi, sehingga manfaat bisnis utama dapat tercapai.

\section{Tabel 3 Hubungan Keterkaitan Manfaat Investasi Sistem TDR}

\begin{tabular}{|c|c|c|c|}
\hline No & Manfaat Bisnis Utama & Tujuan Investasi & Kesejahteraan Digital \\
\hline \multirow[t]{3}{*}{1.} & \multirow{3}{*}{$\begin{array}{l}\text { Mengurangi biaya uang/bunga } \\
\text { pinjaman } \\
(\mathrm{RCO}-09)\end{array}$} & Likuiditas terjaga & \multirow{5}{*}{ Meningkatkan efisiensi } \\
\hline & & Minimalisasi risiko dan biaya & \\
\hline & & Transparan dan akuntabel & \\
\hline \multirow[t]{2}{*}{2.} & \multirow{2}{*}{$\begin{array}{l}\text { Peningkatan pendapatan yang } \\
\text { disebabkan oleh meningkatnya } \\
\text { kapasitas bisnis } \\
\text { (IRE-01) }\end{array}$} & Transparan dan akuntabel & \\
\hline & & Optimalisasi return & \\
\hline \multirow[t]{4}{*}{3.} & \multirow{4}{*}{$\begin{array}{l}\text { Peningkatan pendapatan yang } \\
\text { disebabkan oleh meningkatnya } \\
\text { segmentasi pasar } \\
\text { (IRE-04) }\end{array}$} & Likuiditas terjaga & \multirow{4}{*}{$\begin{array}{c}\text { Pasar yang lebih luas dan } \\
\text { efisien }\end{array}$} \\
\hline & & Minimalisasi risiko dan biaya & \\
\hline & & Transparan dan akuntabel & \\
\hline & & Optimalisasi return & \\
\hline
\end{tabular}

\subsection{Kuantifikasi Manfaat Bisnis Utama}

Kuantifikasi manfaat bisnis utama bertujuan menghitung nilai ekonomi yang akan diperoleh organisasi dengan investasi sistem TDR. Dalam menyusun asumsi (perkiraan) pada suatu proyek, terdapat metode yang disebut three points estimating, yang terdiri dari optimistic, most likely, dan pessimistic (www.projectmanagement.com). Pada penelitian ini, angka yang digunakan dalam menyusun asumsi/perkiraan terbatas pada angka most likely.

1. Mengurangi Biaya Uang/Bunga Pinjaman

Pengurangan biaya uang/bunga pinjaman diperoleh dari aktivitas konversi valas. Dalam rangka memenuhi kewajiban pembayaran (likuiditas), pemerintah melakukan konversi mata uang rupiah ke mata uang asing atau sebaliknya melalui BI. Dengan sistem TDR, pemerintah dapat melakukan konversi tersebut melalui bank umum dengan keuntungan mendapat rate yang lebih kompetitif serta memungkinkan untuk melakukan cross currency. Asumsi-asumsi yang digunakan adalah sebagai berikut:

a. Counterpart meliputi 4 (empat) Bank BUMN (Direktorat Jenderal Perbendaharaan, 2016).

b. Nominal transaksi sebesar \$100 juta. Berdasarkan wawancara dengan perbankan, nominal yang yang mampu diserap oleh bank umum dan memberikan rate terbaik adalah \$20-25 juta per transaksi. Dengan jumlah counterpart empat, maka nominal transaksi yang digunakan adalah $\$ 100$ juta.

c. Frekuensi transaksi adalah rata-rata transaksi/konversi valas yang dilakukan pemerintah dalam waktu satu tahun berdasarkan data tahun 2016 dan 2017, yaitu 19 transaksi.

d. Selisih kurs adalah rata-rata selisih kurs spesial BI dan kurs pasar selama tahun 2016 dan 2017, yaitu 30,05 basis poin.

Rumus perhitungan pengurangan biaya uang/bunga pinjaman adalah:

$=$ nominal transaksi $x$ selisih kurs $x$ frekuensi transaksi

$=\$ 100.000 .000 \times 30.05 \times 19$

$=$ Rp57.090.891.892, - selama 1 tahun, atau

$=$ Rp285.454.459.459, - selama 5 tahun.

2. Peningkatan Pendapatan yang Disebabkan oleh Meningkatnya Kapasitas Bisnis (IRE-01)

Dengan investasi sistem TDR, proses transaksi penempatan uang negara yang semula membutuhkan waktu 3 (tiga) hari dapat diselesaikan dalam waktu 1-2 jam. Selisih waktu tersebut dapat meningkatkan pendapatan karena menambah jangka waktu (tenor) penempatan uang. Asumsi-asumsi yang digunakan adalah sebagai berikut:

a. Nominal transaksi adalah rata-rata nominal transaksi penempatan uang negara di bank umum selama tahun 2016 dan 2017 sebesar Rp2.083.783.783.784,--

b. Frekuensi adalah rata-rata jumlah transaksi penempatan uang negara di bank umum yang dilakukan melalui sistem TDR dalam kurun waktu satu tahun, yaitu 19 pada tahun 2016 dan 2017 dan diasumsikan 28 pada tahun 2018 sampai dengan 2020. 
c. Selisih waktu transaksi merupakan selisih waktu hasil percepatan proses transaksi menggunakan sistem TDR, yaitu 2 (dua) hari.

d. Rate transaksi adalah rata-rata rate penempatan uang negara di bank umum berdasarkan data tahun 2016 dan 2017 sebesar 6,35\% (enam koma tiga puluh lima persen).

e. Jumlah hari dalam setahun adalah 365 hari.

Rumus peningkatan pendapatan yang disebabkan oleh meningkatnya kapasitas bisnis sebagai berikut:

$=\frac{\text { nominal transaksi } x \text { frekuensi } x \text { selisih waktu } x \text { rate }}{\text { Jumlah hari }}$ Jumlah hari

$=2 \times\left(\frac{\mathrm{Rp} 2.083 .783 .783 .784 \times 19 \times 2 \times 6,35 \%}{365}\right)$

$+3 x\left(\frac{\mathrm{Rp} 2.083 .783 .783 .784 \times 28 \times 2 \times 6,35 \%}{365}\right)$

$=$ Rp88.477.156.008, - selama lima tahun.

3. Peningkatan Pendapatan yang Disebabkan oleh Meningkatnya Segmentasi Pasar (IRE-04)

Pemanfaatan sistem TDR memungkinkan pemerintah bertransaksi dengan bank umum, tidak hanya dengan BI. Peningkatan segmentasi pasar juga menambah jenis instrumen yang dapat di transaksikan, meliputi penempatan uang negara di bank umum dan pengelolaan investasi SBN.

a. Penempatan Uang Negara di Bank Umum

Semula penempatan uang negara hanya dapat dilakukan di BI. Dengan sistem TDR, penempatan uang negara dapat dilakukan di bank umum dengan rate yang tentunya lebih tinggi dari remunerasi yang diberikan oleh BI. Asumsi-asumsi yang digunakan sama dengan manfaat Peningkatan Pendapatan yang Disebabkan oleh Meningkatnya Kapasitas Bisnis (IRE-01), dengan tambahan asumsi sebagai berikut:

1) Jumlah maksimal penempatan uang negara di bank umum adalah Rp4,7 triliun.

2) Selisih rate merupakan selisih rate yang diperoleh dari rate pasar dikurangi dengan rate remunerasi, yaitu sebesar $2,34 \%$.

3) Tenor merupakan rata-rata jangka waktu penempatan uang negara di bank umum selama tahun 2016 dan 2017, yaitu 15 hari kalender.

Rumus peningkatan pendapatan yang disebabkan oleh meningkatnya segmentasi pasar penempatan uang negara di bank umum sebagai berikut:

$=\frac{\text { nominal } x \text { frekuensi } x \text { tenor } x \text { selisih rate }}{\text { jumlah hari }}$
$=2 x\left(\frac{\mathrm{Rp} 2.083 .783 .783 .784 \times 19 \times 15 \times 2,34 \%}{365}\right)$
$+3 x\left(\frac{\mathrm{Rp} 2.083 .783 .783 .784 \times 28 \times 15 \times 2,34 \%}{365}\right)$

$=\mathrm{Rp} 244.613 .258 .489,-$ selama lima tahun.

b. Pengelolaan Investasi SBN

Pengelolaan investasi SBN merupakan salah satu bentuk peningkatan segmentasi pasar dalam rangka pengelolaan kas negara. Pengelolaan investasi SBN dilakukan dengan pembelian/penjualan secara putus (outright) atau repo/reverse repo di pasar sekunder. Pengelolaan SBN merupakan jenis investasi baru, yang memberikan pilihan bagi pemerintah untuk memanfaatkan idle cash. Asumsi-asumsi yang digunakan adalah sebagai berikut:

1) Nominal transaksi adalah uang negara yang dapat dikelola melalui instrumen investasi SBN, mengacu pada limit transaksi SBN per hari, yaitu Rp300 miliar (Kementerian Keuangan RI dan Bank Indonesia, 2017).

2) Tenor SBN merupakan jangka waktu SBN yang ditransaksikan. Karena instrumen TDR bersifat jangka pendek, maka tenor yang dipilih 1 (satu) tahun.

3) Yield SBN merupakan rata-rata imbal hasil SBN tenor 1 tahun selama tahun 2016 dan 2017 berdasarkan sumber data www.investing.com, yaitu $6.46 \%$.

4) Selisih rate merupakan selisih yang diperoleh dari yield SBN dikurangi dengan rate remunerasi, yaitu sebesar 2,45\%.

Rumus perhitungan yang digunakan adalah:

$=$ nominal transaksi $x$ selisih rate

$=\mathrm{Rp} 300.000 .000 .000 \times 2,45 \%$

$=\mathrm{Rp} 7.350 .000 .000,-$ selama 1 tahun, atau

$=$ Rp36.750.000.000, - selama 5 tahun.

Berdasarkan perhitungan manfaat di atas, maka rumus peningkatan pendapatan yang disebabkan oleh meningkatnya segmentasi pasar selama 5 tahun adalah:

$=$ penempatan uang negara di bank umum + pengelolaan investasi SBN

$=\mathrm{Rp} 244.613 .258 .489+\mathrm{Rp} 36.750 .000 .000$

$=$ Rp281.363.258.489, -

Berdasarkan kuantifikasi masing-masing manfaat bisnis pada pembahasan sebelumnya, total kuantifikasi manfaat ekonomi seperti terlihat pada Tabel 4. 


\section{Tabel 4 Manfaat Ekonomi Sistem TDR} (dalam milyar rupiah)

\begin{tabular}{|c|r|r|r|c|}
\hline Tahun & \multicolumn{1}{|c|}{ RCO-09 } & \multicolumn{1}{c|}{ IRE-01 } & \multicolumn{1}{c|}{ IRE-04 } & Total \\
\hline 2016 & 57.09 & 13.78 & 45.45 & 116.32 \\
\hline 2017 & 57.09 & 13.78 & 45.45 & 116.32 \\
\hline 2018 & 57.09 & 20.31 & 63.49 & 140.89 \\
\hline 2019 & 57.09 & 20.31 & 63.49 & 140.89 \\
\hline 2020 & 57.09 & 20.31 & 63.49 & 140.89 \\
\hline Total & 285.45 & 88.48 & 281.36 & 655.29 \\
\hline
\end{tabular}

Berdasarkan Tabel 4, total manfaat ekonomi selama lima tahun adalah Rp655.29 milyar dengan urutan manfaat dari yang tertinggi adalah mengurangi biaya uang, peningkatan segmentasi pasar, dan peningkatan kapasitas bisnis. Hasil simulasi system dynamics menggunakan perangkat lunak VensimPLE versi 7.2a juga memberikan total manfaat seperti terlihat pada Gambar 8 .

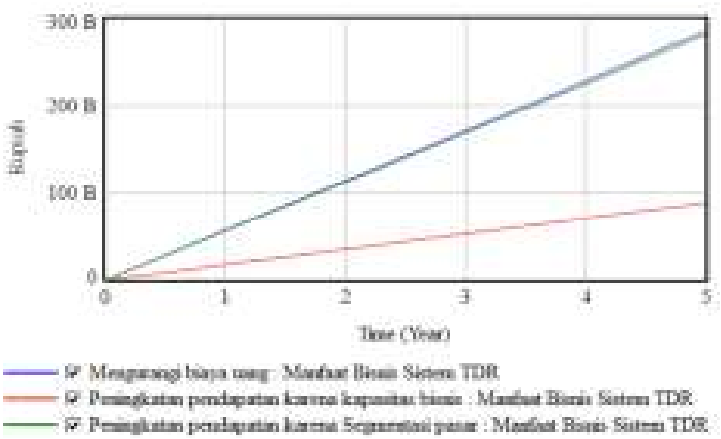

Gambar 8 Hasil Simulasi Manfaat Ekonomi Sistem TDR

\subsection{Identifikasi Risiko Manfaat Investasi Sistem TDR}

Dalam mencapai manfaat bisnis utama investasi sistem TDR, terdapat risiko yang mungkin muncul dan dapat menghambat pencapaian manfaat bisnis tersebut. Pada bagian ini akan dilakukan identifikasi risiko terhadap masingmasing manfaat bisnis untuk memperoleh potensi risiko serta KRI. Identifikasi risiko dilakukan dengan mengacu pada COSO Enterprise Risk Management-Integrated Framework (COSO ERM Framework). Identifikasi risiko dilakukan berdasarkan hasil wawancara dan diskusi yang diolah menggunakan metode analisis tematik.

Dalam analisis tematik, penulis mengelompokkan potensi risiko ke dalam 4 (empat) kategori, yaitu REGU, yang menunjukkan risiko dari segi peraturan (regulation), COOR, yang menunjukkan risiko dari sisi koordinasi (coordination), TECH, yang menunjukkan risiko dari segi teknologi (technology), dan yang terakhir HURE, yang menunjukkan risiko dari sisi Sumber Daya Manusia (human resources).

1. Risiko Manfaat Mengurangi Biaya Uang/Bunga Pinjaman (RCO-09)
Pengurangan biaya uang/bunga pinjaman diperoleh dari aktivitas transaksi/konversi valas melalui bank umum dalam rangka memenuhi kebutuhan likuiditas. Dari sisi regulasi internal, risiko yang muncul adalah belum adanya peraturan yang memayungi transaksi konversi valas dengan bank umum. Tanpa adanya peraturan/dasar hukum, maka transaksi konversi valas dengan bank umum tidak dapat dilakukan, sehingga manfaat pengurangan biaya uang/bunga pinjaman tidak akan tercapai. Dari sisi eksternal, koordinasi dengan BI selaku pengelola kebijakan moneter juga berpengaruh terhadap pencapaian manfaat pengurangan biaya uang/bunga pinjaman. Selaku pengelola kebijakan moneter, BI berwenang memberikan izin kepada pemerintah terkait transaksi valas dengan pihak di luar BI, dalam hal ini bank umum. Belum adanya izin prinsip dari BI terkait transaksi valas dengan bank umum menyebabkan transaksi ini belum dapat dilakukan, sehingga manfaat investasi sistem TDR juga tidak dapat tercapai. Pertimbangan besarnya nilai konversi valas yang dapat mengganggu pasar mungkin dapat dikoordinasikan dengan memberikan limit transaksi yang lebih kecil, sehingga tidak mengganggu kestabilan pasar, namun tetap dapat memberikan keuntungan bagi pemerintah, dalam hal ini mengurangi biaya uang/bunga pinjaman.

Pada sisi teknologi, berdasarkan hasil user acceptance test dan uji coba dengan bank umum, sistem yang ada sudah mampu untuk melakukan analisis dan transaksi valas. Dari sisi SDM, jenis pekerjaan di TDR berbeda dengan pekerjaan pada unit Ditjen Perbendaharaan lainnya, sehingga membutuhkan pengetahuan dan keahlian khusus yang tidak dimiliki oleh pegawai pada umumnya. Adanya mutasi, promosi, dan pegawai tugas belajar menuntut adanya pergantian pegawai/pejabat. SDM pengganti yang belum memahami penggunaan sistem TDR dapat menghambat operasional TDR yang pada akhirnya berpengaruh pada pencapaian manfaat investasi sistem TDR.

2. Risiko Manfaat Peningkatan Pendapatan yang Disebabkan oleh Meningkatnya Kapasitas Bisnis (IRE-01)

Peningkatan kapasitas bisnis disebabkan oleh percepatan transaksi penempatan uang negara di bank umum. Selisih penyelesaian transaksi dapat dimanfaatkan untuk menambah tenor transaksi, sehingga menghasilkan peningkatan pendapatan dari pengelolaan kas negara. Manfaat bisnis ini merupakan jenis manfaat yang sudah terealisasi, sehingga identifikasi risiko juga mempertimbangkan peristiwa/kejadian yang sudah terjadi selama tahun 2016 dan 2017.

Dari segi peraturan internal, saat ini dasar hukum yang dibutuhkan untuk melakukan 
penempatan uang di bank umum sudah lengkap. Namun demikian, risiko peraturan bisa juga disebabkan oleh adanya perubahan kebijakan baik internal maupun eksternal. Sebagai contoh, pada Bulan Mei tahun 2016, perubahan kebijakan internal berdampak pada berhentinya aktivitas penempatan uang negara di bank umum selama dua bulan (Gambar 9, revisi 1). Hal ini karena adanya revisi peraturan dalam rangka mendukung kebijakan pemerintah untuk mendorong pertumbuhan ekonomi sektor riil dengan menetapkan rate maksimal penempatan uang negara di bank umum (Kementerian Keuangan RI, 2016b). Perubahan kebijakan eksternal juga berpotensi menimbulkan risiko peraturan. Kebijakan BI yang merubah suku bunga acuan dari BI rate menjadi BI 7-day repo rate menuntut pemerintah menyesuaikan peraturan penempatan di bank umum (Kementerian Keuangan RI, 2017).

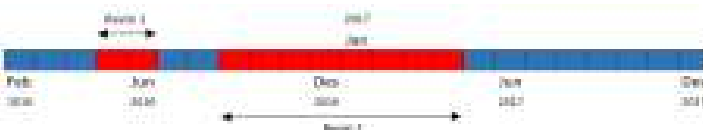

\section{Gambar 9 Bulan Efektif Transaksi Penempatan Uang Negara di Bank Umum}

Revisi peraturan yang membutuhkan waktu sekitar delapan bulan tersebut menyebabkan penempatan uang negara di bank umum tidak dapat dilakukan (Gambar 9, revisi 2). Lamanya proses yang dibutuhkan untuk melakukan revisi dapat dikurangi dengan adanya koordinasi yang lebih baik antara pemerintah dengan BI. Dengan komunikasi di awal terkait perubahan kebijakan, pemerintah dapat mengantisipasi atau mempersiapkan perubahan yang diperlukan, sehingga operasional TDR tidak terhenti/stagnan dalam waktu yang cukup lama.

Pada sisi teknologi, tidak ada permasalahan/risiko signifikan yang ditemukan. Sistem yang ada sudah mampu digunakan untuk analisis dan transaksi penempatan uang di bank umum. Seperti halnya pada manfaat mengurangi biaya uang/bunga pinjaman, risiko kompetensi SDM juga ditemukan pada manfaat peningkatan pendapatan yang disebabkan oleh meningkatnya kapasitas bisnis.

3. Risiko Manfaat Peningkatan Pendapatan yang Disebabkan oleh Meningkatnya Segmentasi Pasar (IRE-04)

Peningkatan segmentasi pasar diperoleh melalui bertambahnya counterpart dan instrumen transaksi. Sebelum implementasi sistem TDR, penempatan idle cash pemerintah hanya dapat dilakukan di BI. Dengan sistem TDR, idle cash pemerintah dapat dikelola melalui penempatan uang negara di bank umum atau investasi SBN. Karena risiko instrumen penempatan uang negara di bank umum telah dibahas pada risiko peningkatan pendapatan yang disebabkan oleh meningkatnya kapasitas bisnis, pada subbab ini akan berfokus pada risiko peningkatan pendapatan yang disebabkan oleh meningkatnya segmentasi pasar khusus untuk pengelolaan investasi SBN.

Risiko peraturan pada pengelolaan investasi SBN adalah adanya peraturan yang belum selesai disusun, yaitu peraturan terkait transaksi repo/reverse repo, sedangkan peraturan untuk transaksi jual beli sudah lengkap. Tanpa adanya peraturan terkait transaksi repo dan reverse repo, maka transaksi tersebut tidak dapat dilakukan, padahal transaksi ini sering dilakukan oleh bank umum baik dalam rangka kelebihan maupun kekurangan kas.

Koordinasi dengan pihak eksternal, dalam hal ini BI dan DJPPR juga dapat menjadi potensi risiko dalam pengelolaan investasi SBN. Koordinasi dengan BI terkait transaksi jual beli SBN yang akan lakukan menggunakan sarana Bank Indonesia Electronic Trading Platform (BI-ETP). Secara infrastruktur BI-ETP sudah siap digunakan, namun dari sisi peraturan BI terdapat pembatasan kepesertaan BI-ETP di mana pemerintah belum termasuk dalam kepesertaan tersebut. Koordinasi dengan BI perlu ditingkatkan agar penyelesaian revisi peraturan dimaksud BI dapat segera dilakukan. Koordinasi dengan Direktorat Jenderal Pengelolaan Pembiayaan dan Risiko (DJPPR) dilakukan dalam rangka stabilisasi pasar SBN. Pada saat kondisi pasar SBN domestik ditetapkan dalam level krisis dan dalam rangka mengantisipasi terjadinya pembalikan (reversal) dana asing, pemerintah dalam hal ini DJPPR perlu melakukan langkah-langkah untuk mengatasi kondisi tersebut (Kementerian Keuangan RI, 2011). Koordinasi dalam hal ini perlu dilakukan agar pengelolaan investasi SBN tidak bertentangan dengan kebijakan penanganan krisis tersebut.

Potensi risiko pengelolaan investasi SBN juga ditemukan dari sisi teknologi. Dalam rangka transparansi, transaksi SBN akan dilakukan dengan mekanisme lelang melalui aplikasi bloomberg. Saat ini fasilitas/fitur lelang belum ada di aplikasi bloomberg. Hal ini menjadi risiko karena hanya pihak bloomberg yang berwenang melakukan perubahan/kustomisasi aplikasi bloomberg, sehingga muncul adanya ketergantungan (dependency) dengan pihak bloomberg. Dari sisi SDM, risiko kurangnya kompetensi pegawai TDR dapat ditindaklanjuti dengan adanya pelatihan (training) berkala untuk meningkatkan kapasitas dealer.

Berdasarkan hasil identifikasi potensi risiko dan KRI pada masing-masing manfaat bisnis utama, diperoleh 11 potensi risiko yang dapat menghambat pencapaian manfaat investasi sistem TDR seperti terlihat pada Tabel 5. 


\section{Tabel 5 Potensi Risiko Pencapaian Manfaat Investasi Sistem TDR}

\begin{tabular}{|c|c|c|c|c|}
\hline Manfaat & Potensi risiko & Indikator Risiko & Mitigasi Risiko & Kategori \\
\hline \multirow{3}{*}{$\begin{array}{l}\text { Mengurangi Biaya } \\
\text { Uang/Bunga } \\
\text { Pinjaman } \\
\text { (RC0-09) }\end{array}$} & $\begin{array}{l}\text { 1. Peraturan/dasar hukum belum } \\
\text { lengkap }\end{array}$ & $\begin{array}{l}\text { Jumlah peraturan yang } \\
\text { belum ada }\end{array}$ & $\begin{array}{l}\text { - } \text { Menyusun seluruh peraturan yang dibutuhkan } \\
\text { - } \quad \text { Berkoordinasi dengan unit peraturan }\end{array}$ & Peraturan \\
\hline & $\begin{array}{l}\text { 2. Belum ada izin prinsip } \\
\text { transaksi dari BI }\end{array}$ & $\begin{array}{l}\text { Izin transaksi belum } \\
\text { disetujui BI }\end{array}$ & Meningkatkan koordinasi dan pembahasan dengan BI & Koordinasi \\
\hline & $\begin{array}{l}\text { 3. Kurangnya kompetensi } \\
\text { pegawai baru }\end{array}$ & $\begin{array}{l}\text { Jumlah pegawai TDR yang } \\
\text { kurang kompeten }\end{array}$ & $\begin{array}{l}\text { - Perekrutan dan pencadangan SDM yang kompeten } \\
\text { - Pelatihan secara berkala }\end{array}$ & SDM \\
\hline \multirow{3}{*}{$\begin{array}{l}\text { Peningkatan } \\
\text { pendapatan yang } \\
\text { Disebabkan oleh } \\
\text { Meningkatnya } \\
\text { Kapasitas Bisnis } \\
\text { (IRE-01) }\end{array}$} & $\begin{array}{ll}\text { 4. } & \text { Revisi peraturan } \\
\text { membutuhkan waktu lama }\end{array}$ & $\begin{array}{l}\text { Waktu penyelesaian revisi } \\
\text { peraturan lama }\end{array}$ & $\begin{array}{l}\text { - Mencari titik yang menghambat proses revisi } \\
\text { - } \quad \text { Meningkatkan koordinasi dengan unit peraturan }\end{array}$ & Peraturan \\
\hline & $\begin{array}{l}\text { 5. Belum ada komunikasi di awal } \\
\text { terkait perubahan kebijakan } \\
\text { oleh BI }\end{array}$ & $\begin{array}{l}\text { Jumlah perubahan } \\
\text { kebijakan yang tiba- } \\
\text { tiba/tanpa komunikasi }\end{array}$ & Meningkatkan koordinasi dan komunikasi dengan BI & Koordinasi \\
\hline & $\begin{array}{l}\text { 6. Kurangnya kompetensi } \\
\text { pegawai baru }\end{array}$ & $\begin{array}{l}\text { Jumlah pegawai TDR } \\
\text { kurang kompeten }\end{array}$ & $\begin{array}{l}\text { - Perekrutan dan pencadangan SDM yang kompeten } \\
\text { - Pelatihan secara berkala }\end{array}$ & SDM \\
\hline \multirow{5}{*}{$\begin{array}{l}\text { Peningkatan } \\
\text { Pendapatan yang } \\
\text { Disebabkan oleh } \\
\text { Meningkatnya } \\
\text { Segmentasi Pasar } \\
\text { (IRE-04) }\end{array}$} & $\begin{array}{l}\text { 7. Peraturan/dasar hukum belum } \\
\text { lengkap }\end{array}$ & $\begin{array}{l}\text { Jumlah peraturan yang } \\
\text { belum ada }\end{array}$ & $\begin{array}{l}\text { - } \text { Menyusun seluruh peraturan yang dibutuhkan } \\
\text { - } \quad \text { Berkoordinasi dengan unit peraturan }\end{array}$ & Peraturan \\
\hline & $\begin{array}{l}\text { 8. Pemerintah belum masuk } \\
\text { dalam kepesertaan BI-ETP }\end{array}$ & $\begin{array}{l}\text { Pemerintah tidak masuk } \\
\text { dalam anggota BI-ETP }\end{array}$ & Meningkatkan koordinasi dan pembahasan dengan BI & Koordinasi \\
\hline & $\begin{array}{l}\text { 9. Operasional TDR bertentangan } \\
\text { dengan kebijakan penanganan } \\
\text { krisis pasar SBN }\end{array}$ & $\begin{array}{l}\text { Jumlah transaksi SBN yang } \\
\text { kontraproduktif dengan } \\
\text { penanganan krisis }\end{array}$ & $\begin{array}{l}\text { Meningkatkan koordinasi dan komunikasi dengan } \\
\text { DJPPR }\end{array}$ & Koordinasi \\
\hline & $\begin{array}{l}\text { 10. Belum ada fitur lelang pada } \\
\text { aplikasi bloomberg }\end{array}$ & Fitur lelang tidak berjalan & $\begin{array}{l}\text { Berkoordinasi dan kerja sama dengan pihak Bloomberg } \\
\text { untuk menyediakan fitur lelang }\end{array}$ & Teknologi \\
\hline & $\begin{array}{l}\text { 11. Kurangnya kompetensi } \\
\text { pegawai baru }\end{array}$ & $\begin{array}{l}\text { Jumlah pegawai TDR yang } \\
\text { kurang kompeten }\end{array}$ & $\begin{array}{l}\text { - Perekrutan dan pencadangan SDM yang kompeten } \\
\text { - Pelatihan secara berkala }\end{array}$ & SDM \\
\hline
\end{tabular}


Potensi risiko paling banyak muncul pada kategori koordinasi, sehingga organisasi perlu memberikan perhatian lebih pada kategori ini. Untuk mencegah/mengurangi dampak dari risiko tersebut, penelitian ini memberikan rekomendasi mitigasi risiko yang dapat dilakukan.

\section{KESIMPULAN DAN SARAN}

Terdapat tiga kesimpulan yang menjawab pertanyaan penelitian berdasarkan hasil analisis dan pembahasan yang telah dilakukan. Pertama, Identifikasi manfaat bisnis sistem TDR menggunakan tabel manfaat bisnis SI/TI generik menghasilkan 7 kategori dan 18 subkategori manfaat yang relevan dan signifikan bagi Ditjen Perbendaharaan, Kementerian Keuangan. Kesimpulan berikutnya berdasarkan kerangka pikir kesejahteraan digital, diperoleh manfaat investasi sistem TDR bagi negara, yaitu meningkatkan efisiensi dan terciptanya pasar yang lebih luas dan efisien. Kesimpulan terakhir terkait pertanyaan penelitian adalah hasil identifikasi risiko menggunakan COSO ERM Framework, menghasilkan 11 (sebelas) potensi risiko yang dapat menghambat pencapaian manfaat ekonomi sistem TDR, yang mencakup aspek peraturan, koordinasi, teknologi dan SDM.

Beberapa saran yang dapat direkomendasikan oleh penulis sebagai berikut:

1. Perlu dilakukan tindak lanjut atas manfaat investasi yang masih berstatus potensi, yaitu transaksi valas dengan bank umum dan pengelolaan investasi SBN, sehingga seluruh manfaat investasi sistem TDR dapat tercapai/terealisasi.

2. Perlu dilakukan evaluasi setelah manfaat bisnis tersebut terealisasi, sehingga dapat memastikan bahwa tujuan investasi tetap terpantau secara berkesinambungan.

3. Perlu dilakukan penelitian yang membandingkan pembiayaan anggaran melalui penerbitan SBN, peminjaman kepada bank umum (borrowing), dan reverse repo SBN untuk memperoleh biaya terbaik dalam rangka pembiayaan anggaran.

\section{IMPLIKASI DAN KETERBATASAN}

Dengan kemudahan yang ditawarkan, tabel manfaat bisnis SI/TI generik dan pendekatan system dynamics dapat dijadikan rujukan dalam proses identifikasi dan pemodelan/simulasi manfaat investasi SI/TI di lingkup Ditjen Perbendaharaan Kementerian Keuangan. Dalam proses penelitian yang dilakukan, ditemui bahwa penggunaan checklist tabel manfaat bisnis SI/TI generik yang diisi oleh individu membutuhkan waktu yang lebih lama karena pengetahuan dan pemahaman responden berbeda-beda. Untuk mengatasi hal ini, dilakukan Focus Group Discussion (FGD). Penggunaan FGD memberikan keuntungan karena bisa dilakukan diskusi secara langsung, sehingga dapat diperoleh pemahaman yang sama.

Dengan keterbatasan perangkat lunak VensimPLE versi 7.2a dalam perhitungan simulasi system dynamics (aspek pembulatan), penelitian selanjutnya dapat menggunakan perangkat lunak lainnya, misalnya menggunakan perangkat lunak anylogic seperti pada penelitian yang dilakukan oleh Prasetya (2017).

Keterbatasan dalam penelitian ini adalah kuantifikasi hanya dilakukan terhadap manfaat bisnis utama sistem TDR, sedangkan manfaat bagi negara tidak dikuantifikasi karena keterbatasan data. Penelitian ini juga tidak melakukan perbandingan pembiayaan anggaran melalui penerbitan SBN, peminjaman kepada bank umum (borrowing), dan reverse repo SBN karena keterbatasan data.

\section{PENGHARGAAN (ACKNOWLEDGEMENT)}

Penelitian ini didanai oleh Lembaga Pengelola Dana Pendidikan (LPDP) Kementerian Keuangan. Selain itu, penelitian ini dapat diselesaikan berkat bantuan rekan-rekan Direktorat Pengelolaan Kas Negara, Direktorat Jenderal Perbendaharaan serta pihak-pihak lain yang tidak dapat kami sebutkan satu per satu.

\section{DAFTAR PUSTAKA (REFERENCES)}

Amri, N. (2014). Analisis Keekonomian Investasi Layanan Data Berbasis Online pada Sistem Manajemen Data Minyak dan Gas Bumi Nasional: Studi Kasus PT Patra Nusa Data. Jakarta: MTI Universitas Indonesia.

Atkinson, R. D., \& McKay, A. S. (2007). Understanding the Economic Benefits of the Information Technology Revolution. Digital Prosperity, (March), 78.

Beasley, M. S., Branson, B. C., \& Hancock, B. V. (2010). Developing Key Risk Indicators to Strengthen Enterprise Risk Management. How Key Risk Indicator Can Sharpen Focus on Emerging Risks, 1-20. Retrieved from papers2://publication/uuid/A17DB7CA6EC5-4F23-84FE-DB4996794C37

Binder, T., Belyazid, S., Haraldsson, H. V, Svensson, M. G., Kennedy, M., Winch, G. W., ... Yanni, J. M. (2004). Developing System Dynamics Models from Causal Loop Diagrams. Proceedings of the 22nd International Conference of the System Dynamics Society. 
Direktorat Jenderal Perbendaharaan. (2016). Keputusan Direktur Jenderal Perbendaharaan Nomor KEP-10/PB/2016 tentang Penetapan Bank Umum Mitra Penempatan Uang Negara. Jakarta.

Direktorat Pengelolaan Kas Negara. (2016). Materi Presentasi Transformasi Pengelolaan Kas Negara. Jakarta: Direktorat Pengelolaan Kas Negara.

Infotech. (2008). How to create an enterprise IT metrics program. Retrieved from https://courses.css.edu/bbcswebdav/pid1052424-dt-content-rid11944261_1/courses/201530-CIS6105-70014FA-21179-M/how-to-create-an-enterpriseit-metrics-program_2_.pdf

Kanungo, S. (2003). Using systems dynamics to operationalize process theory in information systems research. ICIS 2003 Proceedings. Retrieved from http://aisel.aisnet.org/icis2003/38

Kementerian Keuangan RI. (2011). Peraturan Menteri Keuangan Republik Indonesia Nomor 188/PMK.08/2011 tentang Tata Cara Penggunaan Saldo Anggaran Lebih Dalam Rangka Stabilisasi Pasar Surat Berharga Domestik. Jakarta.

Kementerian Keuangan RI. (2016a). Peraturan Menteri Keuangan Republik Indonesia Nomor 115/PMK.05/2016 tentang Perubahan atas Peraturan Menteri Keuangan Nomor 03/PMK.05/2010 tentang Pengelolaan Kelebihan/Kekurangan Kas Pemerintah. Jakarta: Kementerian Keuangan RI.

Kementerian Keuangan RI. (2016b). Peraturan Menteri Keuangan Republik Indonesia Nomor 77/PMK.05/2016 tentang Perubahan atas Peraturan Menteri Keuangan Nomor 3/PMK.05/2014 tentang Penempatan Uang Negara Pada Bank Umum. Jakarta: Kementerian Keuangan RI.

Kementerian Keuangan RI. (2017). Peraturan Menteri Keuangan Republik Indonesia Nomor 53/PMK.05/2017 tentang Perubahan Kedua atas Peraturan Menteri Keuangan Nomor 3/PMK.05/2014 tentang Penempatan Uang Negara pada Bank Umum. Jakarta: Kementerian Keuangan RI.

Kementerian Keuangan RI, \& Bank Indonesia. (2017). Perjanjian Kerja Sama antara Kementerian Republik Indonesia dengan Bank Indonesia Nomor PRJ-262/PB/2017 Nomor 19/6/PKN/DpG/2017 tentang Transaksi Surat Berharga Negara di Pasar Sekunder dan Penatausahaan Surat Berharga
Negara Dalam Rangka Pengelolaan Dana. Jakarta: Kementerian Keuangan RI, Bank Indonesia.

Kementerian Keuangan RI, Bank Indonesia, \& Otoritas Jasa Keuangan. (2016). Keterangan Pers Bersama Nomor: PERS01/SET/FKPPPK/2016 Pengembangan dan Pendalaman Pasar Keuangan untuk Mendukung Pembiayaan Pembangunan Nasional. Jakarta: Kementerian Keuangan RI, Bank Indonesia, Otoritas Jasa Keuangan.

Larasati, P. (2014). Analisis Manfaat Investasi eVoting pada Penyelenggaraan Pemilu Nasional: Studi Kasus Pemilihan Presiden Republik Indonesia. Jakarta: MTI Universitas Indonesia.

Nugroho, K. W. A. (2015). Analisis Manfaat Ekonomis dan Risiko Implementasi Proyek Customer Relationship Management (CRM): Studi Kasus PT Telkomsel. Jakarta: MTI Universitas Indonesia.

Peppard, J., \& Ward, J. (2016). The Strategic Management of Information Systems: Building A Digital Strategy. United Kingdom: Wiley.

Prasetya, W. (2017). Analisis Manfaat dan Kelayakan Bisnis Investasi Software Defined Networking/Network Functions Virtualization (SDN/NFV) Pada Jaringan Core Fiber To The Home (FTTH): Studi Kasus PT Indosat M2. Jakarta: MTI Universitas Indonesia.

Ranti, B. (2008). Identification of Information Systems/Information Technology Business Values with Hermeneutic Approach: Cases in Indonesia.

Ranti, B., \& Nugroho, W. S. (2017). Diktat Kuliah Manajemen Investasi TI. Jakarta: Universitas Indonesia.

Saunders, M., Lewis, P., \& Thornhill, A. (2016). Research Methods For Business Students (Vol. 53). London: Pearson Education Limited. https://doi.org/10.1017/CB0978110741532 4.004

Sekaran, U., \& Bogie, R. (2013). Research Methods for Business: A Skill Building Approach. Chicester: John Wiley \& Sons, Ltd.

Sterman, J. D. (2000). Business dynamics: Systems thinking and modeling for a complex world. Management. https://doi.org/10.1057/palgrave.jors.26013 36 